\title{
1. Employee Relations in Context: Globalization, Uncertainties, and Dynamics of Change
}

\section{Aurora Trif and Valentina Paolucci}

\section{INTRODUCTION}

Globalization, which refers to the process of increased integration between countries, has had significant effects on employee relations (Lansbury, 2018). Economic liberalism, a key feature of globalization, has fostered individualism and competition since the 1980s, hindering collective mechanisms aimed at limiting 'a race to the bottom' in labour standards in many countries (Doellgast et al., 2018). Despite being one of the causes of the 2008 financial crisis, the neo-liberal political discourse has become, over the past decade, a one-size-fits-all recipe for structural reforms with the blessing of international bodies, such as the International Monetary Fund (IMF), the World Bank and the European Union (EU). In the EU, most governments have sought to reduce unemployment and/or contain labour costs primarily by weakening the role of statutory and/or collective bargaining regulations in setting labour standards (Koukiadaki et al., 2016; Marginson, 2015). Thus, economic liberalism during the crisis has reduced the role of institutional mechanisms (e.g. collective bargaining and labour laws) and increased the role of market forces in the regulation of employee relations.

This chapter investigates the effects of recent global changes on employee relations. It examines the impact of major trends in the global environment on the two main mechanisms that regulate employee relations in capitalist societies, namely institutions and markets (Hall and Soskice, 2001). Considering the rise of individualism and unregulated labour markets across the world, it focuses on recent developments in employee relations in Eastern Europe, 
which can be considered an extreme case of radical change towards international liberalization since the 1990s, in a context of rather weak labour institutions (Bernaciak and Kahancova, 2017). It draws particularly on our qualitative empirical data gathered in 2015 for an EU project on the impact of the 2008 crisis on precarious work, focusing on nine Eastern European countries and Greece (Trif et al., 2016). The experiences of workers and employers in countries with limited workers' protection are becoming increasingly relevant for understanding the future of employee relations in developed countries, in a context where unregulated markets facilitate the transfer of labour practices from developing to developed countries (to reduce labour costs) rather than vice versa.

In addition, this chapter examines recent developments in two multinational corporations (MNCs) (based in developed countries) exemplifying the polar opposites of individualized approaches to managing people, namely 'hard' human resource management (HRM) in Ryanair and 'soft' HRM in Google. It is concluded that in this ever-changing global environment, work-related demands are not fundamentally different from those in the nineteenth century, when labour markets were unregulated. As such, they (only) have to be (re)framed by employee relations actors through the inclusive language of solidarity.

\section{IMPACT OF RECENT GLOBAL CHANGES ON EMPLOYEE RELATIONS: A VICIOUS CYCLE?}

Employee relations refers to managing interactions between workers and their representatives (e.g. trade unions, works' councils, workers' director etc.), on the one hand, and employers and their representatives (e.g. employers' associations or managers) on the other hand (Frege and Kelly, 2013). In contrast to a human resource management (HRM) perspective, which focuses on individual interactions between workers and their managers (and considers employee relations as an element of HRM), we use this term from an industrial relations perspective. Consequently, we focus on collective interactions between trade unions organized or unorganized employers which, in turn, frame the individual interactions between workers and managers. We consider that employee relations and HRM are interlinked as 'two sides of the same coin'. ${ }^{1}$ The relationships 
between worker representatives and employers (i.e. social partners) are primarily contingent on the institutional and structural contexts in which they are embedded, as will be discussed next (Schmalz and Dörre, 2018).

\section{Dynamics of Changes in Institutional Context: Is It All Worth It?}

In capitalist countries, labour institutions consist of two interrelated elements, namely employment protection legislation and intermediary institutions that establish labour standards (Schmalz and Dörre, 2018). First, the legislation sets substantive outcomes for workers, such as minimum labour standards (e.g. minimum wage and maximum working time etc.) and procedural outcomes, such as job security (e.g. hiring and firing rules) and provisions concerning collective rights (e.g. freedom of association, collective bargaining and the right to strike). Second, intermediary institutions set the actual substantive (e.g. wages and working time) and procedural (e.g. how to deal with grievances) employment conditions contingent on the up-to-date context at a specific level (e.g. company, group of companies or sector and cross-sectoral). The two main parties that establish those regulations are trade unions or other worker representatives (e.g. works councils and workers' directors etc.) on the one side, and representatives of organized or unorganized employers, on the other. Collective bargaining is the main mechanism used by the social partners to reconcile their conflicting interests and set common rules on both substantive and procedural aspects of work at various levels. The outcome of this form of negotiation is a collective agreement that generally provides mutual benefits for both parties, including social peace and a degree of flexibility (Paolucci, 2017). In addition, trade unions, employers' associations and specialized government agencies can be involved in tri-partite cross-sectoral forums and consultations (e.g. regarding wages or a wider agenda resulting in social pacts) or provide input into social and economic policy at the national level.

Comparative employee relations literature indicates that recent changes in the global economy have primarily challenged the role of intermediary institutions in setting labour standards (Doellgast

et al., 2018; Lansbury, 2018; Lévesque and Murray, 2002). The increased integration between countries achieved through the liberalization of international trades has presented governments with 
the challenge of adjusting their national institutions to improve economic performance. After 2008, in order to gain competitive advantage, most governments (with the notable exception of China) introduced policies seeking to reduce the influence of collective actors and institutions on the labour market, under the premise that solidaristic rules hinder economic growth (Koukiadaki et al., 2016).

\section{Key Challenges for Workers}

Policies aimed at deregulating the labour market have increased the scope for a 'race to the bottom' in labour standards (Marginson, 2015). First, it has become more difficult to reconcile the interests of workers and employers within bi-partite (e.g. collective bargaining) and/or tripartite forums; and, over time, the relationship between the social partners has deteriorated (Doellgast et al., 2018). Second, the decline of joint regulation has reduced the capacity of the social partners to maintain close bonds with their respective constituencies. As a result, fragmentation both within the labour movement and employers' associations has increased (Koukiadaki et al., 2016). Third, greater labour market flexibility has produced new forms of work that often escape national institutional arrangements (e.g. on shared platforms), leading to uncertainty for all stakeholders: workers, employers and society at large (Dundon, 2018). Although cross-country divergence still exists, contingent on the institutions which survived the 2008 crisis, the overall trend is towards weaker labour market regulation. Consequently, within countries variation in labour standards is increasing.

Apart from resulting in higher inequality in society (OECD, 2018), the declining role of collective bargaining as a joint mechanism to set working conditions has undermined unions' legitimacy (Trif and Stoiciu, 2017). Governments, often with the support of international financial institutions and/or the EU (e.g. via the European Semester), have undermined the mechanisms framing multi-employer bargaining fostering 'disorganized decentralization' (Marginson, 2015). This, in turn, has led to a reduction of collective bargaining coverage, particularly in countries where extension mechanisms were recognized by law (e.g. Greece and Romania) (Visser, 2016). Furthermore, bargaining decentralization has reduced the incentives for employers to enter into meaningful negotiations with trade unions at all levels, paving the way to concession bargaining whereby the employer sets 
the agenda and makes the most substantial gains. Moreover, the scope of collective bargaining has become narrower as individual employers have gained more leeway to unilaterally impose terms and conditions of employment, including pay, working time and workload (Müller et al., 2019). Finally, as a result of the reduction of institutional support, unions' actions have become more contingent on the values and principles of their leaders (Schurman et al., 2017).

Post-2008 legal changes have also undermined individual employment protection in many countries. First, the job security of employees on standard contracts was reduced by making it easier for employers to hire and fire employees (Rubery et al., 2016). Second, labour law changes have liberalized different forms of contracts for services, such as agency worker, self-employment (including workers on shared platforms) and outsourcing by using domestic or international suppliers (Lansbury, 2018). Third, new legal provisions have given employers more control over work schedules by removing existing restrictions on overtime and working hours both for standard and non-standard workers. For instance, recent legislation allows employers to increase or decrease the number of working hours per week of standard employees contingent on employers' needs, in countries such as Greece, Romania and Slovenia (Trif et al., 2016). As a result of both increased flexibility for employers to set working time and teleworking it has become more difficult for authorities (e.g. labour inspectors) to verify whether legal provisions concerning working time or minimum wage are applied.

Evidence in Eastern European countries reveals that these legal changes have led to a wide range of illegal or semi-legal practices, such as declaring shorter working hours, using part-time contracts for full-time workers and supplementing workers' income with untaxed cash-in-hand; this is done by employers primarily to reduce payroll taxes (Trif et al., 2016). Workers, on the other hand, tend to accept cash-in hand, enticed by short-term benefits and underestimating the negative impact that tax avoidance has on public service provisions: from pensions and social benefits to healthcare and education. In a context with limited institutional mechanisms to create incentives for employers (and workers) to observe labour standards, the enforcement of statutory and voluntary regulation has become increasingly contingent on the values of local managers.

The weakening of both individual and collective employment rights has eroded workers' solidarity (to various degrees across countries) (Doellgast et al., 2018). On the one hand, less individual 
protection, together with the emergence of new (flexible) forms of work, has fostered individualism and increased competition between workers, based on their personal characteristics (e.g. gender, age, ethnicity, skills, type of work contracts or union membership) (Schurman et al., 2017). On the other hand, the reduction of collective rights has diminished the legal protection offered to unions by the State thereby delegitimizing their role in society. The impact has been greater in Eastern Europe and in Anglo-Saxon countries where, prior to the 2008 crisis, labour institutions were already weak (Müller et al., 2019). Here, the lack of institutional support has forced unions to rely mainly on member action. As a result, it has become more difficult to defend the interests of the most vulnerable groups of workers who are generally not unionized. Also, protecting vulnerable workers, such as those on precarious contracts, can have indirect effects on the working conditions of union members who, over time, may become hostile. This growing division amongst workers has reduced the capacity of unions to build strength through solidarity and, as a result, also to improve labour standards.

In recent times, comparative studies have focused almost exclusively on the challenges faced by labour following the deterioration of institutional constraints (Schurman et al., 2017; Marginson, 2015). For instance, in their influential book on how to reduce precarious work in the current global environment, Doellgast et al. (2018) argue that employers profit from weak institutions and liberalized international markets because deregulation has a clearcut, downward effect on labour costs in the short-term. Nonetheless, there is substantial evidence in the extant literature that labour market institutions, namely, collective bargaining, can have positive effects for companies in the long-term, by providing stability and facilitating mutually advantageous exchanges between employers and employees (e.g. Geary and Trif, 2011; Streeck, 1988). Hence, post-2008 labour market deregulation, particularly the decline of multi-employer bargaining arrangements, has reduced not only the capacity of unions to protect employees, but also the opportunity for employers to shape industrial policy.

\section{Key Challenges for Employers}

Although in recent years global changes have increased the leeway for employers to set unilaterally terms and conditions of employment, 
unregulated labour markets may also have been detrimental to employers (Streeck, 1988). The weakening of extension mechanisms for collective bargaining, together with the decline of collective bargaining coverage, makes it easier for unscrupulous employers to ignore labour laws (Koukiadaki et al., 2016). While large employers are in a stronger position to use legal loopholes to their advantage (e.g. outsourcing, agency work or relocation) (Doellgast et al., 2018), small and medium-sized enterprises (SMEs) are more likely to use illegal (e.g. no employment contracts) or semi-legal practices (e.g. cash-payments on top of minimum wage) to reduce labour costs (Schurman et al., 2017; Trif et al., 2016). In order to avoid unfair competition arising from the greater use of informal practices by SMEs, large temporary agencies (e.g. Addecco, Manpower etc.), which operate in one of the most deregulated and rapidly growing sectors post-2008, have recently set up their own employers' associations in Eastern Europe (Trif et al., 2016). These associations are trying to influence national policies by (re)shaping labour standards; the chairman of the Romanian association indicated that it was in favour of increased regulation, namely, obliging client companies (i.e. employers using agency workers) to provide the same (or better) working conditions for agency workers as for their direct employees (Trif et al., 2016).

Somewhat paradoxically, the international association of employers in the temporary agency work sector, the World Employment Confederation, is at the forefront of EU lobbying for more labour regulation to establish a level playing field for employers, albeit supporting an easy to hire-and-fire 'employment friendly' environment. Remarkably, this employers' organization argues that the strongest performing labour markets (e.g. those with the highest labour productivity) are in countries 'with a high level of social dialogue such as the Netherlands and Scandinavian countries where employers and trade unions typically work together to set specific market legislation that can then be adjusted in line with labour market changes' (World Employment Confederation, 2018: 35). In addition, it supports novel regulations to protect individuals rather than jobs, which could also suit the increasing number of (bogus) self-employed (World Employment Confederation, 2018). Thus, the challenges faced by employers in extremely deregulated labour markets has led to their (re)organizing as collective actors seeking to secure regulations that ensure mutually beneficial outcomes 
for workers and employers, as a means (as in the past) to reduce competition amongst employers.

Furthermore, the recognition by employers in the emerging unregulated labour markets of the mutual benefits of institutional constraints demonstrates that intermediary institutions can still generate benefits for capital. In countries with strong labour institutions, such as Denmark, the Netherlands and Finland, organized employers, together with trade unions, continue to maintain a strong incentive to protect their employment relations systems, due to the overall positive outcomes these secure for all parties involved (Müller et al., 2019). For instance, attempts by some employers to weaken collective bargaining in Denmark were unsuccessful (Doellgast et al., 2018) as it was impossible to uphold the neo-liberal discourse that this institution undermines competitiveness in a country with over 80 per cent collective bargaining coverage and one of the highest levels of labour productivity in the world (Visser, 2016).

In Denmark, the majority of employers consider that their organizations benefit from collective bargaining. Paolucci's study (2016) shows that both employers and HR managers value the opportunity to maintain an ongoing dialogue between social partners, seeking to develop joint actions to address the emerging economic and technological challenges posed by the crisis. In 2014, a senior official of one of the larger employers' associations in Denmark (Dansk Industry) reported:

[M]any employers from other countries shake their heads when they hear how we deal with trade unions. We are not at war with trade unions; we negotiate with the best interest of Denmark in mind. For example, the energy sector is important and we are together with the unions on that. When we think that jobs may be moved from Denmark to foreign countries we join forces and we try to influence the government.

This respondent also indicated that:

Training has become more and more important over the past ten years. I can't remember one sector level negotiation where training was not mentioned. Training helps employers to update the skills of unskilled employees and to train the skilled employees, making them better. ${ }^{2}$

The empirical evidence shows that it can be in the best interest of employers (and not just trade unions) to fight against the deterioration 
of labour institutions which guarantee stability and produce mutually beneficial outcomes for employers and their workers.

Despite an overall trend towards labour market deregulation, there is divergence in employers' preferences for labour institutions. On the one hand, collective bargaining continues to play an important role in countries with a strong (and stable) tradition of multi-employer arrangements, such as in Northern Europe (Müller et al., 2019). Collective bargaining is still supported by most Danish employers, because it enables them to gain competitiveness in the global market by relying on highly trained multi-functional employees (Paolucci, 2016). On the other hand, there have been timid attempts to restore the protection of the most vulnerable groups of workers in countries with very weak labour institutions, such as agency workers in Eastern Europe. Apart from organizing them, a significant recent development is the change in public discourse in relation to precarious work contracts. In Poland, for example, the perception of short-term civil contracts shifted from being seen as useful to boost employment, to being just 'junk contracts' (Mrozowicki et al., 2013). This diffident call to restore labour market institutions in extremely deregulated contexts supports Streeck's (1988: 421) prediction that 'capitalism may just be too important to be left to the capitalists - who arguably are the least capable of protecting it from its self-destructive tendency to pursue cheap and short-term advantages'. Although labour market deregulation increases the power imbalance in favour of capital, both parties in employee relations encounter challenges when the mutual long-term 'beneficial constraints' associated with collective regulation cease to exist.

\section{Dynamics of Change in the Structural Context: Is the Market No One's Friend?}

Recent changes in the global business context have made employee relations increasingly contingent on market forces (Myant and Drahokoupil, 2012). The liberalization of international trade, together with free flows of capital (and labour), has increased competition between firms pressurizing particularly domestic firms to reduce labour costs. These changes make it easier for capital to invest where labour standards are lower, while allowing foreign companies to compete with domestic ones (Batt, 2018). Nonetheless, very large MNCs are more likely than other firms to benefit from increased 
globalization. They have the financial resources to invest or relocate to countries with lower labour costs and/or low corporate tax; moreover, some of them have special tax arrangements with local governments and benefit from transfer pricing (able to declare their profits in countries with low corporation tax, such as Ireland) (Regan and Brazys, 2018). Furthermore, a significant share of their exports of goods and services is intra-firm and, therefore, determined by internal decisions, not external market prices (Lansbury, 2018). In addition, the emergence of shared platforms for different services (e.g. Uber, Airbnb etc.) have put pressure on traditional firms to reduce labour costs, as the workforce on shared platforms is not (yet) entitled to minimum statutory labour standards. These actions of a relatively small number of companies reduce the margin of profit for the other companies, which in turn, intensifies a quest for lower labour costs. Apart from fostering a hostile environment for labour, the increased market competition has also contributed to increased divisions amongst employers.

Besides, the growing interconnectivity of production/service networks across the world makes it difficult to determine where decisions concerning employee relations are made. First, shareholding (the dominant form of ownership) facilitates intricate equity ownership relations in funds and funds of funds, which makes it almost impossible to identify the owners (Lansbury, 2018). Second, the growing use of multiple tiers of suppliers by large companies makes it difficult to determine who sets the labour standards, particularly for the growing share of non-standard workers. The cost of labour for suppliers is often negotiated (or imposed) by the lead company in a supply chain, even for suppliers employing highly skilled workers with a greater capacity to disrupt services, such as pilots. For instance, the terms of the 2016 agreement in the US between Amazon and Atlas Air to transport their Prime products put pressure on the carrier to pay its pilots well below the prevailing market rate (Levy, 2017). Third, it is very difficult to find out which managers are responsible for labour standards in large MNCs with complex organizational structures; sometimes, local managers claim that decisions concerning labour are taken at higher levels, while regional (or headquarter) managers claim that decisions are taken by local managers (Trif and Stoiciu, 2017). Although increased interconnectivity and internationalization of production and services networks present a greater opportunity for workers to disrupt production (Silver, 2003), the ambiguity and 
fragmentation of employers and workers make it difficult (but not impossible) for workers to take collective action to disrupt production.

In addition, the intensification of labour emigration from countries with lower wages to those with higher wages enables employers to provide worse working conditions for migrants than non-migrant workers (Doellgast et al., 2018). For instance, in the EU, there has been an intensification of emigration from the east to the west after the EU accession of the post-communist countries in the 2000s (Eurostat, 2018). Although increased emigration led to a tighter labour market in Eastern Europe, it generally triggered wage increases only for managers and highly skilled professionals, as migrant workers from further east filled lower skilled jobs (e.g. Ukraine, Moldova, China and Vietnam) (Stan and Erne, 2015). Migrant workers are more likely to accept lower wages (and jobs below their qualifications) than non-migrant workers, as wages in their home country are often significantly lower than in the host countries (e.g. up to 10 times lower in Eastern Europe compared to Western Europe) (Eurostat, 2018).

Migrants, together with other vulnerable groups, particularly young workers, are more likely to accept different forms of insecure jobs which, in the long run, may undermine working conditions for the core labour force (Doellgast et al., 2018). In the past, it was primarily workers in low-skilled jobs who had precarious working conditions, while over the last decade it has become more common for highly skilled professionals, such as academics, engineers and researchers to experience insecurity during their careers (Harney et al., 2014). The increase in competition between individuals and/or various categories of workers to get (or retain) a stable job places pressure particularly on highly skilled workers and managers to work beyond the maximum legal working hours; this is not sustainable in the longer run, as either their health or the quality of their work (or both) is likely to deteriorate (Rubery et al., 2016). Thus, the current global business environment forces different categories of workers into a vicious cycle (Doellgast et al., 2018).

Moreover, technological changes introduced over the last 10 years allow employers to use individual workers as suppliers of services (Batt, 2018). Work contracts, ranging from (bogus) self-employed, to agency worker or outsourced/insourced worker, are used by companies to avoid paying payroll taxes and other benefits that employees with a contract of service are entitled to (Bernaciak and 
Kahancova, 2017). Contingent on national culture and customs, other employers may argue that they have to use different forms of illegal or semi-legal contracts for their workers to avoid bankruptcy. Recent changes in technology have also led to the automation of many tasks and jobs, while somewhat paradoxically also supporting longer working hours, often above the legal limits. Not only does technology enable many workers to do their tasks remotely and outside office hours, it also makes it possible for consumers to use services $24 / 7$ and for employers to control workers' activities (Lansbury, 2018). Thus, technological changes play a key role in blurring the boundaries between employers, workers and customers, trapping society in a culture of consumerism where each individual strives to maximize utility towards short-term benefits.

Overall, recent changes in the global environment have contributed to a shift in capitalism from a profit-seeking to a rent-seeking system, where shareholders accumulate significant amounts of profit without creating new wealth (Piketty, 2015). The 'rent' refers to Adam Smith's division of income into profit, wage, and rent (Stiglitz, 2012). In a traditional profit-seeking capitalist system value is created through work. The cost of labour is determined by the supply of and demand for labour (i.e. the market mechanism). The distribution of wealth is based on engaging in (so-called) mutually beneficial transactions between employers (buyers of labour) and workers (sellers of labour). Such 'mutually' beneficial transactions are a voluntary process of exchange based on rational choice, where both parties are better off. This does not necessarily mean that both parties benefit equally from such transactions (e.g. payday loans where a person takes a credit of 100 euro to make ends meet while s/he needs to pay back 200 euro is considered a mutually beneficial transaction). In a similar vein, in profit-seeking capitalism employee relations are based on a market mechanism that redistributes wealth in the form of profit for employers and wages for workers. However, in this process employers benefit far more than workers (Batt, 2018). Moreover, reliance on market mechanisms to set labour standards has contributed to a widening gap between high and low wage earners; in the US, the top 1 per cent of wages have increased by 150 per cent over the last three decades, while the bottom 90 per cent of wages have increased by only 15 per cent according to Stiglitz (2012).

In contrast to the traditional system, rent-seeking capitalism refers to shareholders accumulating income through legal or illegal methods 
that bypass market mechanisms, without creating new wealth (Piketty, 2015). Although rent-seeking, in the form of lobbying (or bribing) politicians for preferential economic regulations such as tariff protection, subsidies and corporate taxes, has been around for a very long time, the emergence of shared platforms that are 'rented' to sellers and buyers of services is a recent phenomenon (Dundon, 2018). These technological developments, together with the international liberalization of trades, have enabled platforms such as Uber, Airbnb and Deliveroo, to become dominant players in the global market, almost overnight, and to generate a significant income for shareholders without creating new wealth (Lansbury, 2018). There are limited market mechanisms to redistribute the income gained through the renting of such platforms, as they have limited (if any) competition for their services and do not act as employers (buyers of labour). Furthermore, many financial organizations also began to use principles of rent-seeking capitalism to increase the income of shareholders without producing wealth in different forms of services, such sub-prime mortgages (Piketty, 2015). Nevertheless, when these practices led to a financial crisis and bankruptcy, in most countries governments bailed banks out by externalizing the risks to society, by increasing taxes for workers and/ or by reducing services for the most vulnerable groups in society (e.g. children, people with disabilities etc.). Thus, technological progress and international liberalization continues to empower a minority of (wealthy) shareholders by shifting the burden of risk onto the majority of (far lower income) individuals.

The growth of rent-seeking capitalism has increased inequality by progressively reducing the capacity of the market to offer mechanisms of wealth redistribution towards mutually beneficial transactions between sellers and buyers of labour. In his seminal book entitled The Price of Inequality, Stiglitz (2012) indicates that the richest 1 per cent held 65 per cent of US national income gains in 2007, while their share increased to 93 per cent in 2010. He writes that: 'Paying attention to everyone else's self-interest - in other words to the common welfare - is in fact a precondition for one's own ultimate wellbeing . . . it isn't just good for the soul; it's good for business' (Stiglitz, 2012: 361). Like Streeck (1988), Stiglitz argues that mechanisms for cooperation should be restored to ensure benefits for all parties. 


\section{BEYOND INSTITUTIONS AND STRUCTURES: IS THE ALTERNATIVE INDIVIDUALIZATION OR COLLECTIVE ACTION?}

Mechanisms aimed at fostering regulation have been dismantled to different degrees across countries in order to boost economic growth and enhance capital and labour mobility through competition (Baccaro and Howell, 2017). The picture we are left with after several decades of aggressive neo-liberal policies is polarized. The world is richer, but inequality is skyrocketing (Piketty, 2015; Stiglitz, 2012). Individuals' capacity to buy goods and services from virtually every corner of the planet has never been greater (Lansbury, 2018). Yet workers' purchasing power has declined due to reducing wages and deteriorating labour standards (Lévesque and Murray, 2002). Work is beyond flexible. Technologies, types of contracts and working hours have given employees the opportunity to redesign the boundaries of their jobs and work from everywhere. However, the perception of insecurity is pervasive and work-related anxiety is on the increase (Broughton, 2010). While the possibility for cross-border mobility expands, cultural cleavages are resurfacing along with requests for protection of national identities (Fukuyama, 2018).

In the ambivalence that permeates modern societies scholars have identified a common trend: individualization (Lansbury, 2018; Lévesque and Murray, 2002). This notion refers to the idea that each person can be responsible for her/his own present and future life. The logic of free-will and liberalization has reshaped society and fostered a 'me-first' attitude. Key features of the employee relationship too, such as autonomy and dependence, have been re-interpreted in terms of individual needs. Over the past thirty years, the field of HRM has played an important role in crystallizing this development. There is now agreement, especially amongst policy-makers, that work should be 'professionally managed' rather than 'socially negotiated' (Meardi, 2014: 595). HR managers can liberate individuals from organizational constraints, opening a path to personal growth and job satisfaction. In turn, employees will be productive and take ownership of their job security and employability (Boxall, 2014). As appealing as that sounds, this discourse has contributed to breaking the link between work and collective action which originated from collectivism; and, in a context where individual autonomy collides 
with solidarity, individuals have become more exposed to external risks and social exclusion (Crouch, 2015).

Scholars who questioned the sustainability of the current capitalist model have struggled to find a way out (Baccaro and Howell, 2017). Due to the significant deterioration in state-provided 'beneficial constraints' (Streeck, 1988) employers, employees and consumers all seem to be trapped in a vicious cycle of high dependence on the market, with reduced opportunities for cooperation (Doellgast et al., 2018). One of the casualties of this short-term, market driven, political agenda are workers and their labour organizations. It is undeniable that capitalism has never encountered less resistance from collective actors (Roche et al. 2014). However, capitalism has also posed challenges that employers can no longer escape. Meanwhile, new complex economic and societal demands are being formulated, especially with regard to equality (e.g. the me too movement) and sustainability. Thus, in this ever-changing scenario, one wonders: can workers' collective voice still be raised?

Ryanair's choice to recognize trade unions and Google protests have shaken the public debate by dispelling the myth that employee relations are irrelevant (Meardi, 2014). The surge of collective conflict in these two companies shows that even in large multinationals embedded in liberal market economies, employees can find opportunities for voicing their discontent and question employers' prerogatives. Despite the erosion of collective bargaining institutions, there are resources that employees can use to advance their demands. Solidarity, as well as conflict, might be silent at work but will never disappear. Old and new forms of labour organizations can revitalize collective action (Bernaciak and Kahancova, 2017).

From an employee relations perspective, Ryanair and Google share elements of similarity as well as difference. They are large internationalized organizations which are market leaders. They both employ highly skilled workers with sufficient structural resources to disrupt services in their respective industries, namely aviation and information technology (IT). Unitarism underpins management approaches in both Ryanair and Google and trade unions have never been recognized as legitimate representative of employees' interests. However, while Ryanair is one of the most notorious cases of hard HRM, Google is an exemplary case of soft HRM. Google has enhanced employees' participation through sophisticated high commitment practices, including individual (voice) channels that 
enable them to have an input into decision making. Whereas, Ryanair has openly repressed any form of internal disagreement (O'Sullivan and Gunnigle, 2009). Somewhat unexpectedly, neither hard nor soft HRM approaches prevented the emergence of workplace conflict and collective action of employees.

Michael O'Leary became the CEO of Ryanair in 1993. For over twenty years, his anti-union stance has led the company to engage in active resistance to independent forms of employee representation. Ryanair has invested in significant efforts to bend the law and reshape the institutional context both in Ireland and other host countries (O'Sullivan and Gunnigle, 2009). The company has relied on a mix of full-time employees and contractors in order to sidestep collective bargaining with pilots (Spero and Beesley, 2018). Moreover, there is a 'no-frills' policy in place for crew staff, who are paid below industry standards and often employed short-term. Over time, Ryanair has become a textbook case of poor personnel management. For many years employees have unsuccessfully demanded better pay and working conditions. Yet, they were unable to take advantage of favourable structural conditions, namely, the requirement for high skills (limited availability of qualified pilots, multiple languages and high mobility), a capital intensive sector (high cost of technology relative to labour) and a customer-driven business. While there were several strikes, until 201790 per cent of all flight schedules remained uninterrupted (Roberts and Griffith, 2018). The company maintained a highly competitive market position becoming the safest and most profitable low-carrier in Europe.

In September 2017, Ryanair employees took industrial action and, for the first time, the company was forced to cancel over 250 flights (BBC News, 18th September 2017). As Ryanair shares fell (down 13 per cent by October 2018), shareholders urged change. In a letter to the company, the Chairman of the Local Authority Pension Fund Forum stated: 'since the annual general meeting (AGM), it appears Ryanair faces a prolonged transition to a more stable employment model and improved IR. As long-term shareholders we believe that Ryanair can continue to grow and prosper, but also consider that this must involve change' (McLoughlin, 2018).

What was it that led to this unforeseen reverse in workers' power? Not only did Ireland provide Ryanair with a business-friendly institutional context, the company also has a history of deliberately circumventing local legislation when expanding into other European 
countries, by employing staff under Irish contracts (O'Sullivan and Gunnigle, 2009). Structural conditions too have remained relatively stable. Perhaps unsurprisingly, it was a grassroots initiative of selforganizing pilots which triggered this turnaround. They used several channels to strengthen their position vis-à-vis the company. First, after the Ryanair cancellation crisis in 2017 a large number of pilots joined trade unions. Second, they set up official company councils in order to 'facilitate and formalize negotiations in line with national and legal social requirements' (Air Traffic Management.net, 2018). Soon afterwards, the most infamous anti-union airline company was forced to capitulate: trade unions were publicly recognized. Third, the Ryanair Transnational Pilot Group was established in anonymity during the 2017 conference organized by the European Cockpit Association. Aided by social media, this international network has helped the Ryanair Employee Representative Councils to share resources (legal, political and technical know-how) as well as to develop negotiating skills. By acting transnationally and striking en masse, the group of workers with the strongest structural power - pilots - derailed Ryanair strategy to negotiate separate agreements with multiple Employee Representative Councils (Davies, 2018). While the battle in Ryanair is still ongoing, pilots initiated a pan European movement through which the lack of workers' institutional resources was, at least partly, overcome. This, in turn, has increased pilots' structural power and, with the support of trade unions, enabled other categories of employees (e.g. cabin crew) to put forward further demands.

The walk-out in Google is an equally fascinating development. The Google motto, 'Don't be evil', together with the autonomy given to employees to find solutions to current challenges contributed to the emergence of a new category of employee, namely 'Googlers'. Apart from having one of the highest wages in the US (Mautz, 2018), Googlers' reward packages include massages, catered meals, generous parental leaves, in situ pools, wellness programmes and other amazing benefits. Their generous reward package reflects the fact that they are considered vital for Google's success. The strategic focus that Google put on people management has heavily influenced the IT industry.

Moreover, Google's approach to employees is widely used for teaching purposes, as an exemplary case of soft HRM. It shows that companies which invest in employees can reap a return through 
productivity, quality and profitability while improving societal wellbeing (Boxall, 2014). In this unique work environment, dominated by the idea that each employee can make the world a better place to live - in a vaguely utopian form of individualism (Scheiber, 2018) conflict does not exist. Googlers trust each other, management included, as they all equally strive to succeed. This is considered the living proof that a perfect alignment between a company's strategic objectives and its employees' needs is possible. The corporate culture offers everyone a purpose that is clear and direct: 'to organize the world's information and make it universally accessible and useful'. It is argued that managers are there to help, whereas trade unions hinder innovation. In this context, why should Googlers seek any form of collective representation?

However, about 20,000 Google employees all over the world staged a series of walk-outs in November 2018. This unprecedented form of collective action took place in Google after several allegations of sexual misconduct were made against senior executives, including one against Andy Rubin, the creator of Android mobile phone software. To secure his departure, the company paid a $\$ 90$ million severance package. In response, employees opened a channel of international communication across all subsidiaries using social media (Walkout for Real Change, 2018) and other internal technologies. As in the Ryanair case, such technologies offered Googlers the opportunity to exploit their (hitherto unused) structural power and overcome the lack of institutional resources, such as their own independent forms of representation.

The demands of Googlers are at odds with that unitarist, individualistic culture celebrated by the company and seemingly shared by all its employees. Of the five specific requests that employees identified, three in particular clash with the claims of a soft HRM approach: (1) protesters asked for an end to forced arbitration in cases of harassment and discrimination, including the right of workers to bring a representative or other supporter when meeting $\mathrm{HR}$; (2) protesters demanded to end pay and opportunity inequity, particularly concerning the gender, race and ethnicity compensation gap; and (3) in order to ensure that their demands are addressed by the management team, Googlers asked for an independent Employee Representative to join the Board of Directors and requested a higher status and additional resources for the existing Chief Diversity Officer (Walkout for Real Change, 2018). As highlighted by Scheiber 
(2018), the most remarkable aspect of the walk out at Google is 'that organisers identified their action with a broader worker struggle, using language almost unheard-of among affluent tech employees' and arguably, many other industries (e.g. workers' solidarity). The Googlers' collective action can be seen as an example of economic liberalism leading to a reactionary countermovement whereby society seeks to re-entrench the economy and society by establishing social protection (Polanyi, 1944).

Interpreting recent developments in employee relations in the Ryanair and Google cases is not straightforward. The main lesson, however, is that collective action is still possible; both cases show that employee voice can become a powerful tool if individuals act together. These cases illustrate that workers' protests and solidarity are essential in reframing the mainstream discourse that highlights the benefits of economic liberalism and individualism to include consideration of its costs for workers and society. These companies used nineteenthcentury practices, such as strikes and walk-outs, to advance social issues (equality, dignity and respect) that have yet to be solved. In Ryanair, the pilots' self-movement was a stepping-stone towards union recognition. It served as a way to mobilize an institutional resource, collective bargaining, which, albeit weakened, has existed since the twentieth century. In 2019, the Ryanair Chief People Officer, Eddie Wilson, was appointed as Chief Executive of the Ryanair airline, while Google has ended forced arbitration, following employee protests. Despite lacking institutions, Google workers were able to enact new structural resources, namely twenty-first century information technologies, reminding employers that they can (if they want to) exert power.

In other words, these two examples show that, when acting collectively, employees have the potential to turn any contingent resource (institutions and/or structures) into power, thereby advancing their demands. In both cases, technologies were essential for employees to establish international links, strengthen solidarity and gain publicity. This shows that technologies do not only make employees obsolete. On the contrary, they can empower them. As Kochan (2019) argues, technology is just a resource: it can be deployed to reshape the future of work in a productive and inclusive way. Perhaps what one should question is agency, namely the role and influence of existing channels for employee representation. Will unions be able to adapt to the current global environment? How will employers react if tensions intensify? 


\section{CONCLUSION}

This chapter examined the impact of recent global changes on the two main mechanisms that regulate employee relations in capitalist societies, namely institutions and markets. First, it confirmed that prevailing policies of economic liberalization all around the world have weakened the role of labour institutions which set 'beneficial constraints' for labour and capital. While employers have benefited far more than workers from this development, their ability to seize the new opportunities offered by the global market varies greatly. Large multinational corporations have a greater capacity than small and medium size enterprises to take advantage of varying labour costs and tax regimes across countries.

Second, the growing share of direct links between sellers and individual buyers, facilitated by technology, has paradoxically undermined the role of the market mechanism in creating mutually beneficial transactions between buyers and sellers of labour. Fast-growing, online (.com) companies are escaping traditional rules governing the 'standard' employment relationship (minimum wage, working-time, health and safety and welfare entitlements) without considering the long-term effects not only on their profitability, but on society too, such as consumer backlash, conflict, and liability. Meanwhile, employers operating in many traditional industries such as manufacturing, retail, hospitality and other business services are been threatened by the growing role of rent-seeking capitalism (Lansbury, 2018). Both these developments are blurring the boundaries between the employer and the employee, while also increasing competition between employers.

Third, against a backdrop of loosening institutional constraints and uncertain market structures, this chapter highlighted the importance of collective action as an alternative to shake the status quo and create new incentives for cooperation between all societal actors. It is argued that employees with the strongest structural resources have the best opportunity to reinvent a more equal and sustainable workplace - they can take advantage of the visibility their companies have, and the technologies they helped develop, to lead a new (labour) movement. Young generations of highly demanding employees, who were hired to change the world (e.g. Googlers), can persuade their employers to abide by the ambitious ethical objectives they set for themselves. Social media offers a platform whereby disenfranchised workers can be heard.

Overall, the 'disruption' created by an increasingly unregulated 
global environment opens a 'Pandora's Box' of uncertainties: neither capital nor labour seems to know whether globalization helps or hinders their relative position in society. The issue is multifaceted and predictions are hard to make. However, this chapter shows that it is not impossible to exercise collective voice even in the highly individualized and competitive modern society. The cases of Ryanair and Google demonstrate that solidarity at work can certainly be rebuilt. It also highlights that workers' demands are the same as in the past and continue to remain unaddressed.

In the current context of weak institutions and volatile market structures, it is unclear whether the traditional employee relations actors - governments, employers and labour movements - will be able to address the challenges created by economic liberalism. Will these actors be willing and able to resort to each other's support to restate cooperation-enhancing institutions, such as collective bargaining or tripartite forums? Will Googlers play a leading role in shifting the dominant discourse from 'economic liberalism' to a global society that ensures 'dignity, equality and respect' for all, perhaps by using the new technology that they themselves create? Will policy-makers and employers consider the argument that it is not only human beings and natural resources that need protection, but that the capitalist system itself also needs to be sheltered from the potentially devastating effects of economic liberalism (Polanyi, 1944; Stiglitz, 2012; Streeck, 1988)? The answer lies with all of us, workers, employers and other groups in society. In particular, our social and political actions (or inaction) shape employee relations and the type of society that we work and live in.

\section{NOTES}

1. Professor Richard Hyman made this analogy during an informal discussion in the early 2000s.

2. Respondent interviewed by Valentina Paolucci for her 2016 study; these quotes were not used in her published work.

\section{BIBLIOGRAPHY}

Air Traffic Management.net 2018. Ryanair pilots signal birth of transnational group, 19 March, Key Publishing, accessed on 27 February 2019, https:// 
airtrafficmanagement.keypublishing.com/2018/03/19/ryanair-pilots-signalbirth-of-transnational-group/.

Baccaro, L. and Howell, C. 2017. Trajectories of Neoliberal Transformation: European Industrial Relations Since the 1970s, Cambridge: Cambridge University Press.

Batt, R. 2018. The financial model of the firm, the 'future of work', and employment relations, in A. Wilkinson, T. Dundon, J. Donaghey and A. Colvin (eds), The Routledge Companion to Employment Relations (pp. 465-79), London: Routledge.

BBC News 2017. Ryanair publishes full list of cancellations, 18 September, BBC, accessed on 8 March 2019, https://www.bbc.co.uk/news/business-41311603.

Beck, U. 2000. Living Your Own Life in a Runaway World: Individualisation, Globalisation and Politics (pp. 164-74), London: Jonathan Cape.

Bernaciak, M. and Kahancova, M. 2017. Beyond the Crisis: Innovative Practices Within CEE Trade Union Movements, Brussels: European Trade Union Institute.

Boxall, P. 2014. The future of employment relations from the perspective of human resource management. Journal of Industrial Relations, 56(4), pp. 578-93.

Broughton, A. 2010. Work-related stress, Eurofound Dublin, accessed on 8 March 2019, https://www.eurofound.europa.eu/sites/default/files/ef_files/ docs/ewco/tn1004059s/tn1004059s.pdf.

Crouch, C. 2015. Governing Social Risks in Post-Crisis Europe, Cheltenham, UK and Northampton, MA, USA: Edward Elgar Publishing.

Davies, R. 2018. Ryanair pilots form unofficial union in battle with Michael O'Leary. The Guardian, accessed on 8 March 2019, https://www.theguardi an.com/business/2017/oct/02/ryanair-pilots-union-michael-o-leary.

Doellgast, V., Lillie, N. and Pulignano, V. (eds) 2018. Reconstructing Solidarity: Labour Unions, Precarious Work, and the Politics of Institutional Change in Europe, Oxford: Oxford University Press.

Dundon, T. 2018. The fracturing of work and employment relations. Labour and Industry: A Journal of the Social and Economic Relations of Work, 28(1), pp. 1-13.

Eaton, A. E., Schurman, S. J. and Chen, M. A. (eds) 2017. Informal Workers and Collective Action, New York: Cornell University Press.

Eurostat 2018. Database, accessed on 8 November 2018, https://ec.europa. eu/eurostat/data/database.

Frege, C. and Kelly, J. 2013. Comparative Employment Relations in the Global Economy, London: Routledge.

Fukuyama, F. 2018. Identity: Contemporary Identity Politics and the Struggle for Recognition, London: Profile Books.

Geary, J. and Trif, A. 2011. Workplace partnership and the balance of advantage: a critical case analysis. British Journal of Industrial Relations, 49(s1), pp. 44-69.

Hall, P. A. and Soskice, D. W.(eds) 2001. Varieties of Capitalism: The Institutional Foundations of Comparative Advantage, Oxford: Oxford University Press.

Harney, B., Monks, K., Alexopoulos, A., Buckley, F. and Hogan, T. 2014. 
University research scientists as knowledge workers: contract status and employment opportunities. The International Journal of Human Resource Management, 25(16), pp. 2219-33.

Kochan, T. 2019. It is not technology that will steal your job, Irish Times, accessed on 13 January 2019 https://www.irishtimes.com/opinion/it-is-nottechnology-that-will-steal-your-job-1.3753547.

Koukiadaki, A., Tavora, I. and Martínez-Lucio, M. 2016. Joint Regulation and Labour Market Policy in Europe During the Crisis, Brussels: European Trade Union Institute.

Lansbury, R. D. 2018. The changing world of work and employment relations: a multi-level institutional perspective of the future. Labour and Industry: A Journal of the Social and Economic Relations of Work, 28(1), pp. 5-20.

Lévesque, C. and Murray, G. 2002. Local versus global: activating local union power in the global economy. Labor Studies Journal, 27(3), pp. 39-65.

Levy, A. 2017. Amazon prime air pilots are heading to shareholders meeting to confront execs over low wages, CNBC 22 May 2017, accessed on 18 November 2018, https://www.cnbc.com/2017/05/22/amazon-shareholdersmeeting-protest-prime-air-pilots.html.

Marginson, P. 2015. Coordinated bargaining in Europe: from incremental corrosion to frontal assault? European Journal of Industrial Relations, 21(2), pp. 97-114.

Mautz, S. 2018. Google, Facebook and Amazon just revealed their median pay and it's a major lesson in employee motivation, accessed on 21 December 2018, https:/www.inc.com/scott-mautz/google-facebook-amazon-just-reve aled-their-median-pay-its-a-major-lesson-in-employee-motivation.html.

McLoughlin, G. 2018. Ryanair investors want chairman replaced, Irish Times accessed on 15 December 2018 https://www.independent.ie/business/irish/ ryanair-investor-wants-chairman-replaced-37467801.html.

Meardi, G. 2014. The (claimed) growing irrelevance of employment relations. Journal of Industrial Relations, 56(4), pp. 594-605.

Mrozowicki, A., Roosalu, T. and Senčar, T. B. 2013. Precarious work in the retail sector in Estonia, Poland and Slovenia: trade union responses in a time of economic crisis. Transfer: European Review of Labour and Research, 19(2), pp. 267-78.

Müller, T., Vandaele, K. and Waddington, J. (eds) 2019. Collective Bargaining in Europe, Brussels: European Trade Union Institute, forthcoming.

Myant, M. and Drahokoupil, J. 2012. International integration, varieties of capitalism and resilience to crisis in transition economies. Europe-Asia Studies, 64(1), pp. 1-33.

OECD 2018. Going for Growth 2018: An opportunity that governments should not miss, OECD, accessed on 8 March 2019, http://www.oecd.org/ eco/going-for-growth.htm.

O'Sullivan, M. and Gunnigle, P. 2009. Bearing all the hallmarks of oppression. Labor Studies Journal, 34(2), pp. 252-70.

Paolucci, V. 2016. The Role of Collective Bargaining in Addressing Flexibility and Security: A Multi-level Comparative Institutional Analysis of Three 
Countries and Four Companies within the Chemical and Pharmaceutical Sector, University of Warwick (IRRU) PhD.

Paolucci, V. 2017. The role of collective bargaining in addressing flexibility and security. European Journal of Industrial Relations, 23(4), pp. 329-46.

Peters, J. 2008. Labour market deregulation and the decline of labour power in North America and Western Europe. Policy and Society, 27(1), pp. 83-98.

Piketty, T. 2015. About capital in the twenty-first century. American Economic Review, 105(5), pp.48-53.

Polanyi, K. 1944. The Great Transformation, Boston: Beacon Press.

Regan, A. and Brazys, S. 2018. Celtic phoenix or leprechaun economics? The politics of an FDI-led growth model in Europe. New Political Economy, 23(2), pp. 223-38.

Roberts, D. L., and Griffith, J. C. 2018. A Tale of Two Airlines: A Comparative Case Study of High-Road Versus Low-Road Strategies in Customer Service and Reputation Management, accessed on 8 March 2019, https://commons. erau.edu/publication/965.

Roche, W. K., Teague, P. and Colvin, A. J. 2014. Introduction: developments in conflict management, in W. K. Roche, P. Teague and A. J. Colvin (eds), The Oxford Handbook of Conflict Management in Organizations (pp. 1-29), Oxford: Oxford University Press.

Rubery, J., Keizer, A. and Grimshaw, D. 2016. Flexibility bites back: the multiple and hidden costs of flexible employment policies. Human Resource Management Journal, 26(3), pp. 235-51.

Scheiber, N. 2018. Google workers reject Silicon Valley individualism in walkout, The New York Times online 6 November, accessed on 8 March 2019, https://www.nytimes.com/2018/11/06/business/google-employee-walkout-la bor.html.

Schmalz, S. and Dörre, K. 2018. The power resources approach. Paper prepared for the project Trade Unions in Transformation, accessed on 8 March 2019, https://www.fes.de/index.php?eID=dumpFile\&t=f\&f=32816 \&token $=\mathrm{e} 509820 \mathrm{f} 9 \mathrm{daab} 00 \mathrm{a} 4 \mathrm{fe} 1 \mathrm{be} 4 \mathrm{f} 4 \mathrm{~d} 052 \mathrm{f} 9 \mathrm{ef} 7085 \mathrm{fc} 9$.

Schurman, S. J., Eaton, A. E. and Chen, M. A. 2017. Conclusion: expanding the boundaries of labour organising and collective bargaining, in A. E. Eaton, S. J. Schurman and M. A. Chen (eds), Informal Workers and Collective Action (pp. 217-37), Cornell: Cornell University Press.

Silver, B. J. 2003. Forces of Labor: Workers' Movements and Globalization Since 1870, Cambridge: Cambridge University Press.

Spero, J. and Beesley, A. 2018. Has Ryanair chief Michael O'Leary lost his costkilling touch? Financial Times online, 4 October, accessed on 8 March 2019, https://www.ft.com/content/2d5671ec-c7d5-11e8-ba8f-ee390057b8c9.

Stan, S. and Erne, R. 2015. Is migration from Central and Eastern Europe an opportunity for trade unions to demand higher wages? Evidence from the Romanian health sector. European Journal of Industrial Relations, 22(2), pp. 167-83.

Stiglitz, J. E. 2012. The Price of Inequality: How Today's Divided Society Endangers Our Future, New York: W. W. Norton \& Company. 
Streeck, W. 1988. Comment on Ronald Dore, rigidities in the labour market. Government and Opposition, 23(4), pp.413-23.

Taskin, L. and Devos, V. 2005. Paradoxes from the individualization of human resource management: the case of telework. Journal of Business Ethics, 62(1), pp. 13-24.

Trif, A., Koukiadaki, A. and Kahancova, M. 2016. The rise of the dual labour market: fighting precarious employment in the new member states through industrial relations: comparative report (Croatia, Czechia, Greece, Hungary, Latvia, Lithuania, Poland, Romania, Slovakia and Slovenia). European Commission. Brussels, Belgium: European Commission.

Trif, A. and Stoiciu, V. 2017. Turning crisis into an opportunity: innovation within the Romanian trade union movement, in M. Bernaciak and M. Kahancova (eds), Beyond the Crisis: Innovative Practices Within CEE Trade Union Movements (pp. 161-77), Brussels: ETUI.

Visser, J. 2016. What happened to collective bargaining during the great recession? IZA Journal of Labor Policy, 5(9), pp. 1-35.

Walkout for Real Change 2018. Google walkout for real change, Twitter Referencing Group, 1 November, accessed on 6 March 2019, https:/www. nytimes.com/2018/11/06/business/google-employee-walkout-labor.html.

World Employment Confederation 2018. Economic report 2017, WEC, accessed on 15 December 2018, https://www.wecglobal.org/fileadmin/media /pdf/WEC_Economic_Report_2018_Edition.pdf. 